ISA

Arboriculture \& Urban Forestry 2017. 43(1):27-37

\title{
Effects of Retention Time in Nursery Containers and Root Pruning at Planting on Landscape Establishment and Anchorage of Three Tree Taxa
}

\author{
Edward F. Gilman, Maria Paz, and Chris Harchick
}

\begin{abstract}
Tree lodging in landscapes during storms has been attributed to root architecture in nurseries. Objectives of this study were to evaluate influence of retention time in three progressively larger nursery containers, and root pruning at landscape planting, on establishment, anchorage, and root architecture in the first four post-planting years. All trees were retained in three progressively larger containers $(11,57$, and $170 \mathrm{~L})$ for a total of 32 months, with varying retention times in each. Retention time had little influence on post-planting xylem water potential for Acer rubrum and Ulmus parvifolia. There were few differences in aboveground growth among retention times. Except for Acer, retention time had a negligible influence on anchorage. Root pruning by shaving $170 \mathrm{~L}$ root ball periphery when planting had no impact on growth except for one post-planting year. However, root pruning invoked a dramatic reduction in circling and descending roots four years after planting caused by root deflection in the final nursery container. Although root pruning had no influence on bending stress required to winch Magnolia trunks to any degree of trunk tilt, approximately $10 \%$ more bending stress was required to winch Acer trunks up to five degrees tilt when root balls were shaved at planting.

Key Words. Acer rubrum; Anchorage; Bending Stress; Magnolia grandiflora; Planting; Post Planting; Root Architecture; Transplanting; Ulmus parvifolia; Xylem Water Potential.
\end{abstract}

Trees and shrubs are easily shifted to larger nursery containers once roots bind substrate together. Shifting too early can result in loss of substrate and possible root deformations as young, non-lignified roots bend down and deform in the process. Retaining trees for a longer period causes roots deflected by container walls to become lignified and stiff in the deformed position; this leaves an imprint on the root system conforming to the container shape and size as the tree ages (Salonius et al. 2000). Thus, retention times that are either too short or too long can cause deformations in the root system, including stem-girdling roots, circling roots, and descending roots that impact health and anchorage (Burdett 1978; Balisky et al. 1995).

Dunn et al. (1997) and Salonius et al. (2000) showed a direct relationship between length of time tree seedlings were retained in propagation containers (retention time) and the development of deformed root systems; longer times resulted in inferior root architecture. Many studies on conifer seedlings show that root deflection in propagation containers can contribute to growth problems in forest plantations (e.g., Krasowski 2003). Roots on shade trees in larger containers also deflect around or downward and proliferate at the bottom of containers (Marshall and Gilman 1998). These and other deformations in the root system can lead to poor rooting out, resulting in unstable trees (Lindgren and Örlander 1978; Gilman and Harchick 2014).

Balisky et al. (1995) provided evidence that root deflection and deformation occurred on trees growing in containers before root density increased sufficiently to facilitate normal extraction, handling, and transportation. For this reason, Lindström et al. (2005) tested a stabilized or reinforced substrate designed to resist the root ball breaking apart and found that the root ball could be removed easily from the container intact before permanent structural roots became deflected 
by container walls. However, few trees destined for landscapes are grown in this substrate (personal observation). Coutts et al. (1990) found that under certain conditions some taxa are stabilized after planting by straight adventitious roots that develop following out-planting from propagation containers. Straight lateral roots radiating from the trunk are associated with well-anchored trees (Lindgren and Örlander 1978; Lindström and Rune 1999; Ortega et al. 2006). In addition to modified (i.e., not solid) container wall design, root pruning during container production (Harris et al. 1971; Gilman et al. 2010) and at landscape planting (Gilman and Wiese 2012) has been associated with an abundance of straight roots growing into the backfill soil and into the landscape soil, and it can be used to improve root architecture.

The objective of this study was to determine the impact of retention time in 11,57 , and 170 L nursery containers, given 32 months total production time in the nursery, and of root pruning at landscape planting on establishment and anchorage during four subsequent growing seasons. The taxa chosen for study were selected due to their popularity in many parts of temperate North America and elsewhere.

\section{MATERIALS AND METHODS}

\section{Growing and Planting Trees}

In February 2007, 80 uniform rooted cutting liners

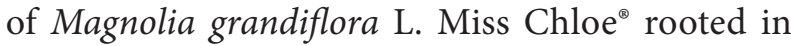
square propagation containers $(7.3 \mathrm{~cm}$ across $\times$ $14 \mathrm{~cm}$ deep smooth-sided, solid-walled, Anderson Band AB39, Stuewe and Son, Inc., Tangent, Oregon, U.S.), and Acer rubrum L. 'Florida Flame' and Ulmus parvifolia Jacq. Allée rooted in circular propagation containers $(5.1 \mathrm{~cm}$ top diameter, $13 \mathrm{~cm}$ tall ribbed, solid-walled, 38 Groovetube, Growing Systems, Inc., Milwaukee, Wisconsin, U.S.) were shifted into $11 \mathrm{~L}$ round, black, solidwalled nursery containers $(27 \mathrm{~cm}$ top diameter, $25 \mathrm{~cm}$ tall; Nursery Supplies, Inc., Chambersburg, Pennsylvania, U.S.). Magnolia roots originated primarily near the end of the stem cutting, whereas roots on Acer and Ulmus emerged near the end and from along the buried stem. The point where the top-most root emerged from the stem cutting was placed approximately $13 \mathrm{~mm}$ below the $11 \mathrm{~L}$ substrate surface by removing an appropriate amount of substrate and deflected roots from the top of liner root ball. The containers were placed on woven black ground cloth in USDA Hardiness Zone $8 \mathrm{~b}$ (mean low temperature $-10^{\circ} \mathrm{C}$ ) in Gainesville, Florida, U.S. Low winter temperatures in January 2008 killed numerous Ulmus resulting in 48 of the 80 trees leafing out in spring; no Acer or Magnolia were damaged by low winter temperatures.

All trees were grown in three progressively larger containers $(11,57$, and $170 \mathrm{~L})$ for a total of 32 months with varying retention times in each container. Twenty Magnolia and Acer, and twelve Ulmus in $11 \mathrm{~L}$ containers were randomly assigned to each of the following four retention-time treatment combinations: 1) shifted June 2007 into 57 L solid-walled containers (black plastic round, $44 \mathrm{~cm}$ top diameter $\times 35 \mathrm{~cm}$ tall, Nursery Supplies Inc., Chambersburg, Pennsylvania, U.S.) after four months in $11 \mathrm{~L}$ and then shifted February 2008 into solid-walled $170 \mathrm{~L}$ containers (75 cm top diameter $\times 47 \mathrm{~cm}$ tall) after eight months in $57 \mathrm{~L} ; 2$ ) shifted September 2007 into $57 \mathrm{~L}$ after seven months in $11 \mathrm{~L}$ and then shifted July 2008 into $170 \mathrm{~L}$ after 10 months in $57 \mathrm{~L}$; 3) shifted November 2007 into $57 \mathrm{~L}$ after nine months in 11 L, and then shifted November 2008 into $170 \mathrm{~L}$ after 11 months in $57 \mathrm{~L}$; and 4) shifted February 2008 into $57 \mathrm{~L}$ after 12 months in $11 \mathrm{~L}$ and then shifted April 2009 into $170 \mathrm{~L}$ after 14 months in $57 \mathrm{~L}$. This resulted in 32 months in nursery containers for all trees (see Retention time in containers, Table 1). Root balls were not pruned when shifting. All trees were retained in $170 \mathrm{~L}$ containers through October 2009, when five trees of each retention-time combination were harvested and root balls dissected for data collection (described in the companion study, Gilman et al. 2015b). This left 15 Acer and Magnolia, and seven Ulmus per retentiontime combination for planting into the landscape.

On 3-6 May 2010, 10 trees randomly selected from the remaining 15 per retention-time combination for Acer and Magnolia were planted into landscape soil (Millhopper fine sand - loamy, siliceous, hyperthermic Grossarenic Paleudults) in a grid pattern $(3.0 \mathrm{~m} \times 3.7 \mathrm{~m})$ so that the top of the root ball was even with the landscape soil. For Magnolia and Acer, root balls of five trees of each retention-time combination were left intact (not pruned); five trees were root pruned for total of 40 planted trees of each taxa. Root pruning was per- 
Table 1. Effect of retention time in container ${ }^{2}$ on post-landscape planting tree height increase, xylem water potential, and visual root imprint rating of Acer.

\begin{tabular}{|c|c|c|c|c|c|c|}
\hline \multicolumn{3}{|c|}{$\begin{array}{l}\text { Retention time (months) } \\
\text { in containers }{ }^{z}\end{array}$} & \multirow[t]{2}{*}{$\begin{array}{l}\text { Tree height } \\
\text { increase }\end{array}$} & \multirow[t]{2}{*}{$\begin{array}{l}\Psi 5 / 19 / 10^{\mathrm{w}}(\mathrm{Mpa}) \\
2011^{\mathrm{y}, \mathrm{x}}(\mathrm{m})\end{array}$} & \multirow[t]{2}{*}{$\begin{array}{l}\Psi 6 / 7 / 10^{\mathrm{w}} \\
(\mathrm{Mpa})\end{array}$} & \multirow[t]{2}{*}{$\begin{array}{l}\text { Visual root imprint rating } \\
\text { from } 57 \mathrm{~L}^{\mathrm{y}, \mathrm{v}} \text { container }(1-5)\end{array}$} \\
\hline $11 \mathrm{~L}$ & $57 \mathrm{~L}$ & $170 \mathrm{~L}$ & & & & \\
\hline 4 & 8 & 20 & $0.7 \mathrm{~b}^{\mathrm{u}}$ & $-1.59 b$ & $-1.50 \mathrm{ab}$ & $2.9 \mathrm{~b}$ \\
\hline 7 & 10 & 15 & $0.8 \mathrm{ab}$ & $-1.56 b$ & $-1.45 b$ & $2.2 \mathrm{~b}$ \\
\hline 9 & 12 & 11 & $1.1 \mathrm{a}$ & $-1.61 b$ & $-1.45 b$ & $4.0 \mathrm{a}$ \\
\hline 12 & 14 & 6 & $0.7 \mathrm{~b}$ & $-1.69 \mathrm{a}$ & $-1.58 \mathrm{a}$ & $4.2 \mathrm{a}$ \\
\hline
\end{tabular}

${ }^{\mathrm{z}}$ All trees were retained in three progressively larger containers $(11,57$, and $170 \mathrm{~L})$ for a total of 32 months with varying retention times in each.

y Tree attribute not affected for Magnolia and Ulmus $(P>0.07)$.

${ }^{\mathrm{x}}$ Height increase 2011 growing season; height increase during 2010, 2012, and 2013 growing seasons not significant $(P>0.06)$.

w $\Psi$ not significant October 2010, March and April $2011(P>0.08)$; Ulmus $\Psi$ was not affected by retention time, and Magnolia was not measured.

${ }^{v}$ Imprint imposed on root system by roots deflecting at the $57 \mathrm{~L}$ nursery container wall; 1 = little imprint, $5=$ highly visible imprint; imprint imposed by $11 \mathrm{~L}$ and 170 L containers not significant $(P>0.16)$.

${ }^{u}$ Means in a column with a different letter are statistically different at $P<0.05 ; \mathrm{n}=10$, mean across root pruning treatment due to insignificant interaction $(P>0.41)$.

formed after placing the root ball in the planting hole and stabilizing it with backfill soil half way up the root ball sides. A sharp $36 \mathrm{~cm}$ long root-balling shovel removed approximately $5 \mathrm{~cm}$ of the periphery of the root ball in a process referred to as shaving. Roots may not have been cut all the way to the bottom of the container sides because the shovel was slightly shorter $(36 \mathrm{~cm})$ than the root ball was tall $(47 \mathrm{~cm})$. Substrate and roots severed by shaving remained in the hole as part of backfill soil. Five from the remaining seven Ulmus per retentiontime treatment combination ( 20 trees) were planted in the same manner without root pruning because there were not enough replicates due to cold winter temperatures killing some trees in the nursery. Branches were not pruned at or after planting.

Trees were surface fertilized with $800 \mathrm{~g}$ of 20-0-8 $\left(\mathrm{N}-\mathrm{P}_{2} \mathrm{O}_{5}-\mathrm{K}_{2} \mathrm{O}\right)$ in June 2010, and $400 \mathrm{~g}$ of 20-0-8 in March and June 2011, on a one meter diameter circle that was centered on the trunk. In order to minimize water stress, trees were irrigated three times daily (with exceptions mentioned hereafter) until 21 May 2010 when it was changed to every other day. Chipped hardwood branches with live foliage from local utility line-clearance operations, aged several months, were applied as mulch $1.8 \mathrm{~m}$ wide and $10 \mathrm{~cm}$ deep along the rows. Glyphosate was applied as needed over mulch to control weeds. Vegetation between rows was periodically mowed.

\section{Tree Measurements}

Each tree was evaluated in early afternoon by two people, independently, and rated for average presence of actively expanding shoots $(1=$ no expanding shoots, 5 = expanding shoots present across the entire crown) and occurrence of wilting new shoots and/or leaves $(1=$ no wilting, $5=$ most leaves and/or actively growing shoots wilting) on 19 and 28 May and 04 June 2010. Irrigation was withheld and no rainfall occurred two days prior to and during each measurement date. Presence of actively growing shoots was again evaluated by two people and averaged 29 July and 08 September 2010. Foliage density $(1=$ few live leaves on the tree, $5=$ dense crown of live foliage) was rated by two people and averaged in September 2010. Trunk diameter was measured at landscape planting $30 \mathrm{~cm}$ from the ground (May 2010) and in September of each of four years after planting. The difference in diameter between May and September 2010 was reported as trunk diameter increase for that growing season; subsequent diameter increases were calculated as the difference between the previous year and current season's September measurements.

Xylem water potential was measured on all 40 Acer and 20 Ulmus in 2010 on sunny days including 19 and 28 May, 07 June, and 18 October, and on 25 March and 26 April in 2011. Magnolia was not measured because of the large diameter of current-year shoots. Irrigation had been withheld and no rainfall occurred two days prior to the measurement dates. Xylem potential 12:00 to 14:00 hr. was measured with a pressure bomb (Soil Moisture, Inc., Santa Barbara, California, U.S.). The terminal portion of one current-year shoot per tree in full sun, about half way up the south side of the crown, was cut about $10 \mathrm{~cm}$ long. Pressure in the air-tight chamber was increased at a constant rate of $30 \mathrm{sec} \cdot \mathrm{MPa}^{-1}$ and was recorded when cut stem surface became uniformly wet.

All trees (20 Ulmus, 40 each of Acer and Magnolia) were winched due east to five degrees trunk tilt from vertical start position to evaluate 
anchorage six (08-10 November 2010) and 18 (14-16 November 2011) months after landscape planting. Trees were winched three rain-free days, after the last measurable rainfall, with an electric winch attached to a cable about $1.2 \mathrm{~m}$ from the ground. The cable remained parallel to ground. A $3,629 \mathrm{~kg}$ capacity load cell (SSM-AF-8000; Interface Inc., Scottsdale, Arizona, U.S.) was placed in-line with the winching cable. An inclinometer (model N4; Rieker Inc., Aston, Pennsylvania, U.S.) was mounted to a fabricated steel plate (5.1 $\mathrm{cm} \times 7.6 \mathrm{~cm})$. The plate was secured to trunk base $15 \mathrm{~cm}$ from the soil surface, which was just above the swollen flare at the trunk base. The cable was winched at $2 \mathrm{~cm} \cdot \mathrm{sec}^{-1}$ until the inclinometer tilted five degrees from vertical start position; the tree was held for 60 seconds, while the distance was measured from the trunk to the deepest point of the soil depression on the leeward side (referred to as hinge point) before relaxing the cable. Final angle at the trunk base was recorded as rest angle 60 seconds after relaxing cable.

Data from the load cell and inclinometer were collected at $2 \mathrm{~Hz}$ by Data Acquisition System (National Instruments Corporation, Austin, Texas, U.S.) and recorded on a laptop. Data were displayed in real-time during winching on a laptop running LabView software (v: 7.0; National Instruments, Austin, Texas, U.S.). Trunk bending stress was calculated according to Equation 1.

$$
\sigma=\frac{F \cdot d \cdot R}{\frac{\pi}{4} \cdot R^{4}}
$$

where

$$
\begin{aligned}
& \sigma=\text { bending stress } \\
& F=\text { pulling force } \\
& d=\text { distance from pulling point to inclinometer } \\
& R=\text { trunk radius (calculated as halving diameter } \\
& \text { measured with a diameter tape at the inclinometer } \\
& \text { position) }
\end{aligned}
$$

In June 2014, an air excavation device removed soil from the top $10 \mathrm{~cm}$ of the soil profile within a $60 \mathrm{~cm}$ radius around each trunk of all Acer and Magnolia to expose roots. Root measurements included: 1$)$ one visual root imprint rating $(1=$ no imprint on the root system; 5 = large imprint) from root deflection conforming to each individual container size $(11,57,170 \mathrm{~L})$, excluding the original propagation container; 2) whether roots forming the imprint either predominantly circled at an angle less than 45 degrees from horizontal (these were circling roots) or predominantly descended at an angle greater than 45 degrees to horizontal (these were descending roots) when deflected at each container size; 3 ) diameter of the five largest roots measured $5 \mathrm{~cm}$ beyond the edge of the planted root ball on the west 90 degree quadrant in the top $10 \mathrm{~cm}$ soil profile; and 4) diameter of the three largest roots circling at the position of the 170 L container. Root diameter was converted to crosssectional area (CSA), assuming roots were circular. Tree height measured from ground to the top of the tree, and trunk diameter using a diameter tape at $30 \mathrm{~cm}$ from ground, were collected on all trees at planting and in each subsequent September.

\section{Statistical Analysis}

Trunk diameter over the period of the study was analyzed with repeated measures analysis of variance (ANOVA) in PROC MIXED of SAS (version 9.2). Other measurements on Acer and Magnolia were analyzed separately using PROC ANOVA two-way factorial ANOVA in a randomized complete block design (4 retention times $\times$ 2 root prunings $\times 5$ blocks $=40$ trees each taxa), with retention time and root pruning as main fixed effects and block as a random factor. Ulmus was analyzed using one-way ANOVA in a randomized complete block design (4 retention times $\times 5$ blocks $=20$ trees) with retention time as the main fixed effect. Bending stress and rest angle were evaluated with a split plot in time (November 2010 and 2011) using PROC GLIMMIX in SAS, with the independent variables retention time, root pruning, and year as main fixed factors, and block as a random factor. Results were reported as significant at $P<0.05$ unless indicated otherwise. Coefficients for regression equations were calculated using PROC GLM in SAS.

\section{RESULTS AND DISCUSSION}

There were no significant interactions between main effects. The main effects (i.e., retention time and root pruning at planting) were significant for at least one measured tree attribute at one point in time. 


\section{Retention Time}

There was no impact of retention time in nursery containers on post-landscape planting visible wilt, presence of active shoot extension, or livefoliage crown density for any of the three taxa tested (data not shown). Ulmus and Magnolia tree height increase and visual root imprint rating from any container size (measured four years after planting) were not impacted by retention time (data not shown). Retention time in nursery containers had no effect on Ulmus trunk diameter growth in the four years after landscape planting (data not shown). In contrast, Acer tree height increase the second growing season after planting (2011) was greatest for trees retained nine months in $11 \mathrm{~L}$ containers (Table 1); however, Acer tree height increase was not affected in the other three growing seasons, and Acer trunk diameter was never impacted (data not shown).

Although Magnolia that had grown for 12 months in $11 \mathrm{~L}$ containers showed greater trunk diameter increase $(21 \mathrm{~mm})$ the first growing season (a five-month measurement period) after landscape planting than for shorter retention times $(7-13 \mathrm{~mm}$, Figure 1), trunks were $10 \mathrm{~mm}$ smaller at planting $(51 \mathrm{~mm})$ than trees retained in the small containers for shorter periods (61 $\mathrm{mm})$. Differences in trunk diameter growth among container retention times were small in subsequent growing seasons. Other researchers also showed that smaller trees can grow faster than larger trees (Watson 1985), although there

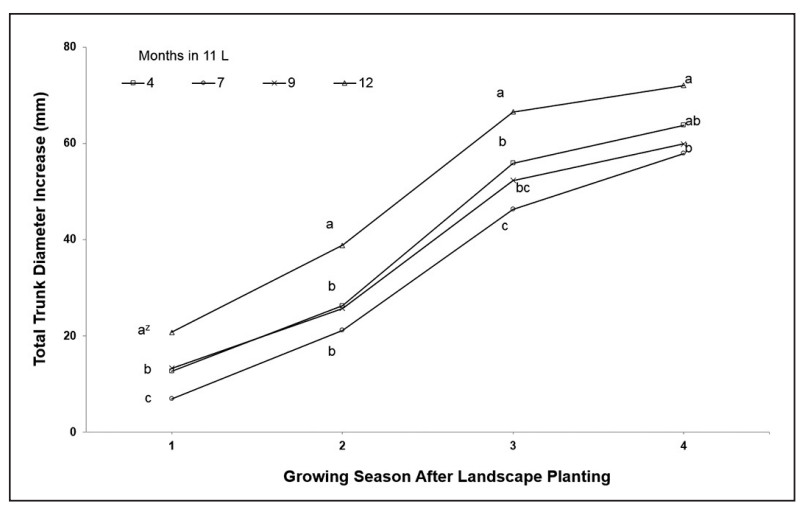

Figure 1. Effect of retention time in $11 \mathrm{~L}$ nursery container on Magnolia trunk diameter increase from landscape planting (May 2010) through September of the indicated growing season (Acer and Ulmus not significant). ${ }^{2}$ Means within a growing season with a different letter are statistically different at $P<0.05 ; n=10$, mean across root pruning treatment due to insignificant interaction $(P>0.17)$. are exceptions (Struve et al. 2000). Therefore, faster growth on Magnolia retained 12 months in $11 \mathrm{~L}$ containers could have been due to either their smaller size at planting or root attributes within the root ball; the data could not differentiate. Except for these small effects, there appeared to be few differences among retention times in growth measured aboveground during the four years after landscape planting for any taxa tested.

Xylem water potential on the first irrigation-free day about two weeks after planting Acer (19 May 2010) was slightly_but statistically significantlower (-1.69 Mpa, Table 1), indicating greater water stress for trees retained the longest time in smaller containers (and correspondingly the shortest time in the largest containers). The greater root density close to the trunk on trees retained longer in the smaller containers (described in Gilman et al. 2015b) could have caused rapid drying of Acer root ball substrate, which could explain the water stress immediately after planting. Water stress after planting containers has been attributed to low water-holding capacity in the soil-less container root ball substrate (Spomer 1980). Xylem water potential was similar among retention times about two weeks later on the second irrigation-free day; there were no differences among retention-time treatments for Acer, subsequently indicating only minor impact of retention time on post-planting water stress. There was no difference in Ulmus xylem water potential at any time attributable to retention time in containers; Magnolia water potential was not measured.

The relatively small effect of retention time in containers on aboveground post-planting growth in the current study appears consistent with Balisky et al. (1995). In contrast, Salonius et al. (2000) found that root systems had more deflected roots (considered defects) at planting, and shoots and roots grew slowly into soil when held in propagation containers for extended periods compared to younger liners. Robert and Lindgren (2006), in summarizing previous work, discussed the unpredictability of aboveground growth response among studies and species from root defects in containers, some resulting from long retention times in containers. Most of these studies were on conifers installed from propagation containers, so trees were less than two years old at planting. Effects 
on growth from varying retention times in larger, shade tree nursery containers have not been studied. Based on the conifer studies cited here, as well as the current study's results, the tested retention times would all be suitable for producing shade trees with comparable post-planting aboveground growth potential in the early years after planting.

Visual root system imprint on Acer from 11 and $170 \mathrm{~L}$ containers measured four years after landscape planting was not affected by retention time in container; however, imprint from the $57 \mathrm{~L}$ container generally increased with retention time in the $57 \mathrm{~L}$ container (Table 1). Most (82\%, data not shown) of the imprint from the $11 \mathrm{~L}$ container on Acer was due to roots deflected around the container (circling roots). Magnolia responded differently, where most (82\%) of the $11 \mathrm{~L}$ container root imprint was due to roots deflected downward at more than a 45 degree angle to the horizontal (descending roots). Acer root imprint at the larger $57 \mathrm{~L}$ container position again was composed primarily (92\%) of circling roots, whereas circling roots represented $72 \%$ of the imprint for Magnolia. The root system imprint on both taxa at the 170 L container position was exclusively from circling, not descending roots. Therefore, Acer roots in the top $10 \mathrm{~cm}$ of soil profile appear to deflect in a circling manner early in their life, whereas those of Magnolia descend, only to circle later. Perhaps this was due to the adventitious roots that orient themselves vertically from the tip of the Magnolia stem cuttings (personal observation) and their naturally deep rooting habit (Burns and Honkala 1990), whereas those of Acer rubrum grow from the stem cutting both horizontally and downward (Gilman et al. 2016), and form a naturally shallow root system (Burns and Honkala 1990).

Root orientation (i.e., vertical versus horizontal) four years after planting represented a large change from root orientation at planting. For example, when trees of all taxa were planted, there was a much higher percentage (up to $88 \%$ depending on taxa and retention time) of the five largest roots that were deflected down the container sidewalls than circled at the position of $11 \mathrm{~L}$ or $57 \mathrm{~L}$ containers (Gilman et al. 2015b). This tendency for downward deflection has been described for young trees in smaller propagation containers than used in the current study for many conifer taxa (e.g.,
Lindström and Rune 1999; Solanius et al. 2000). The change over four years in orientation of roots contributing to the root imprint from deflecting downward to deflecting in a circling manner indicates that the largest roots that were oriented downward at planting were not the ones contributing substantially to the visual root imprint four years later. Instead, smaller roots that circled at planting in the top $10 \mathrm{~cm}$ of the root ball appear to have been invigorated during the four years after planting because they comprised the majority of the root imprint at the end of the study. This could be due to the tendency for roots of some taxa close to the surface to proliferate after planting. For example, roots on Acer rubrum from seed (Gilman and Kane 1990) and from cuttings (Gilman et al. 2014) that emerge close to the substrate surface often grow large at the expense of those borne deeper in the root ball. Coutts et al. (1990) also showed this trend on lodgepole pine (Pinus contorta Dougl.) and Sitka spruce (Picea sitchensis Bong. Carr.).

Given the lack of response aboveground to differences in root architecture brought about by retention time, the vascular system in roots appears to function normally even with 90-degree bends from roots deflected down or around container walls, at least while plants were young in this study. However, when deflections are severe enough, roots can wrap and constrict the trunk (Watson and Clark 1993) and other roots (Lindström and Rune 1999), which can negatively impact health and can reduce anchorage (Lindström and Rune 1999). The more severe root deformations sometimes observed in landscapes may be the result of longer retention times in containers than tested in this study, or deformations may take longer to develop than the four-year observation period in this study.

Retention time in nursery containers did not impact bending stress to winch Ulmus or Magnolia trunks to five degrees tilt, hinge point at five degrees tilt, or rest angle immediately following release of the winching cable (data not shown). This occurred despite significant differences among retention times in root architecture within the root ball at planting (Gilman et al. $2015 b)$, suggesting that changes within the root ball resulting from retention time did not impact anchorage. In contrast, other researchers found increased retention time in propagation con- 
tainers influenced anchorage years after planting conifers; however, these trees were very small when planted from propagation containers (Salonius et al. 2000), compared to the much larger and older trees in the current study. Scots pine (Pinus sylvestris L.) trees planted from $75 \mathrm{ml}$ propagation containers developed spiraling (circling) roots, which caused the trees to be less stable in the soil seven to nine years after planting than naturally regenerated trees, but not fifteen years after planting (Lindström and Rune 1999), indicating the adaptability or plasticity of root systems.

In contrast to Ulmus and Magnolia, Acer retained for the shortest period (four months) in smaller containers-concomitant with the longest time in $170 \mathrm{~L}$ containers (20 months)-required less bending stress to winch trunks to five degrees tilt than trees in longer retention times (Figure 2). This indicated that Acer retained in $11 \mathrm{~L}$ containers for four months were slightly less stable in the landscape than those retained longer. Although ANOVA showed no significant difference in bending stress among the longer retention times in $11 \mathrm{~L}$ containers (Figure 2), a graph of the data suggests that anchorage may have declined for retention time greater than nine months in $11 \mathrm{~L}$ containers (Figure 3). However, only about $21 \%$ of bending stress could be accounted for by retention time, leaving $79 \%$ to factors not measured (Equation 2). Those factors can include structural root straightness and visual root system imprint on trees planted from $57 \mathrm{~L}$ containers (Gilman and Wiese 2012). Models for some species in forest plantations established from propagation containers can sometimes explain a large portion of the variation in tree stability from factors that include mass of the root-soil plate (roots and soil bound together close to the trunk), rooting depth and architecture, and soil type (Coutts 1983; Stokes 1999; Fourcaud et al. 2008). It is not clear if these same factors are also important for stability of trees planted from large nursery containers typical of the landscape industry such as trees in the current study. Size and dimensions of the container root ball-which was confounded with tree age-has been shown to influence anchorage of Acer rubrum planted from nursery containers (Gilman et al. 2014). The equation for predicting Acer bending stress $(\sigma)$ to winch trunks to five degrees tilt is as follows:

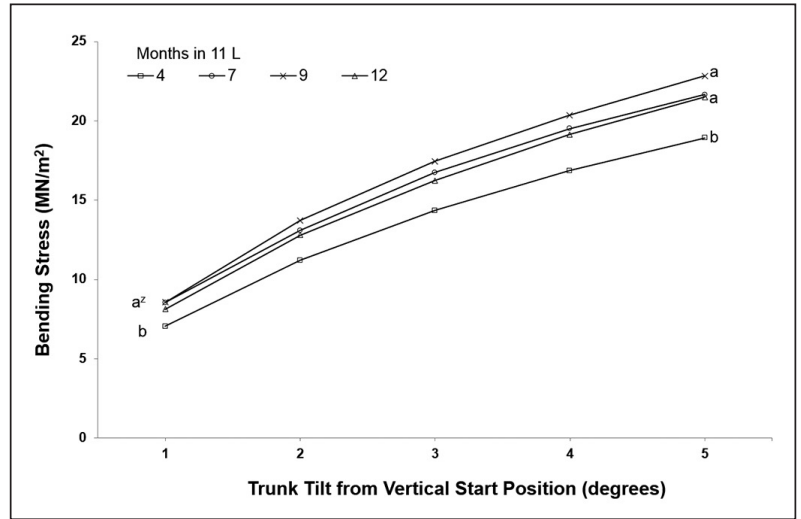

Figure 2. Effect of retention time in $11 \mathrm{~L}$ nursery container on trunk bending stress required to tilt Acer trunk base to five degrees. ${ }^{2}$ Means for each degree of tilt with a different letter are statistically different at $P<0.01$; $n=20$, mean across root pruning and year (2010 and 2011) due to insignificant interaction $(P>0.29)$. Trees planted May 2010 and winched 6 and 18 months later.

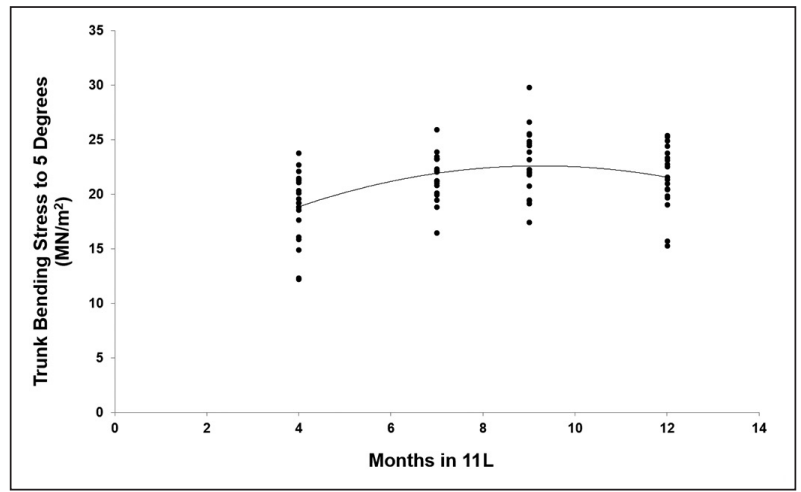

Figure 3. Effect of retention time in $11 \mathrm{~L}$ nursery container on trunk bending stress required to tilt Acer trunk five degrees from vertical start position. Bending stress for UImus and Magnolia was not affected by retention time.

$\sigma=10.94+2.52$ (months in $11 \mathrm{~L}$ container) -

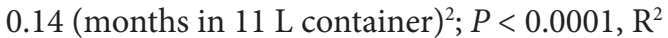
$=0.21$ (Figure 2 ).

More roots could have been displaced during shifting from the $11 \mathrm{~L}$ four-month retention treatment as substrate broke away from the root ball and dislodged roots vertically than from root balls retained longer (Gilman et al. 2015b). This may have resulted in fewer roots growing horizontal and straight - such roots have been associated with stability on Acer rubrum (Gilman et al. 2014) and Quercus virginiana Mill. (Gilman and Wiese 2012). There was some evidence in the current study that roots became dislodged vertically when shift- 
ing Acer retained four months in $11 \mathrm{~L}$ containers. For example, these trees showed significantly less CSA in the largest roots within the dimensions of the $11 \mathrm{~L}$ and $57 \mathrm{~L}$ containers during nursery production (Gilman et al. 2015b); neither of the other two taxa tested showed this trend at planting. Acer trunks in the $11 \mathrm{~L}$ four-month retention time were also smaller at planting than for all other retention times. Despite the statistically significant reduction in anchorage for Acer retained four months in 11 L containers, retention time as tested in this study appears to only negligibly influence anchorage. Perhaps a longer retention time in some of the container sizes-as could occur in some nurseries-would be necessary to impart larger differences in anchorage.

\section{Root Pruning}

Except for one post-planting year, root pruning by shaving off the root ball periphery when Acer and Magnolia trees (Ulmus was not included in the root pruning treatment) were planted into the landscape had no impact on any measured aboveground attribute (data not shown). The one exception was trunk diameter increase in the third growing season after planting (2012), which was $5 \mathrm{~mm}$ less on Magnolia root pruned at planting than on those not pruned (Table 2). The same Magnolia in a related study (Gilman et al. 2015c) also grew slightly slower (about 5\%) in response to shaving the $170 \mathrm{~L}$ container root ball at planting. In contrast to aboveground attributes, shaving the root ball at planting had a strong affect $(P<$ $0.0001)$ on visual root system imprint and CSA of circling roots four years after planting. Root pruning reduced the root imprint by a factor of three or more, and nearly eliminated circling roots on both taxa tested (Table 2). Shaving the periphery of the $170 \mathrm{~L}$ container had no impact on root defects at the $11 \mathrm{~L}$ or $57 \mathrm{~L}$ positions (data not shown).

Other studies showed that effects on root architecture from root pruning by shaving root balls during nursery production (Gilman et al. 2010) or when planting into field soil (e.g., Gilman et al. 2016) were far greater than effects of nursery container type. The current study also shows that rootball shaving influenced root architecture more so than retention time in nursery containers. Therefore, root pruning appears to be an important tool for developing root systems with a minimum of root deflections in the nursery and landscape.

Root pruning had no impact on bending stress required to winch Magnolia trunks to any degree of trunk tilt up to five degrees, six and 18 months after landscape planting $(P>0.10$, data not shown). However, compared to not root pruning, approximately $10 \%$ more bending stress was required to winch Acer trunks up to five degrees tilt when root balls were shaved at planting six and 18 months earlier (Figure 4). Other researchers have found a statistically significant but small increase in anchorage $(<12 \%)$ when Quercus virginiana were shaved of peripheral roots at planting (Gilman and Wiese 2012), or a small (8\%) but statistically significant decrease for Magnolia grandiflora (Gilman et al. 2015c). Experience with one species (Acer platanoides L.) showed that remediation a decade or

Table 2. Effect of root pruning when landscape planting (May 2010) on trunk diameter increase, visual root imprint from container, and CSA of the largest circling roots at $170 \mathrm{~L}$ container position in subsequent four years.

\begin{tabular}{|c|c|c|c|c|}
\hline Root pruning ${ }^{z}$ & $\begin{array}{l}\text { Trunk diameter increase } \\
2012 \text { growing season }{ }^{y}(\mathrm{~mm})\end{array}$ & $\begin{array}{l}\text { Visual root imprint rating } \\
\text { from } 170 \mathrm{~L}^{\mathrm{x}} \text { container }(1-5) \\
\text { at } 170 \mathrm{~L} \text { position }{ }^{\mathrm{w}}\left(\mathrm{mm}^{2}\right)\end{array}$ & $\begin{array}{l}\text { CSA largest diameter root } \\
>5 \mathrm{~mm} \text { diameter circling } \\
\text { at } 170 \mathrm{~L} \text { position }{ }^{\mathrm{w}}\left(\mathrm{mm}^{2}\right)\end{array}$ & $\begin{array}{l}\text { Total CSA three largest roots } \\
>5 \mathrm{~mm} \text { diameter circling }\end{array}$ \\
\hline \multicolumn{5}{|l|}{ Acer } \\
\hline Yes & $26 \mathrm{a}^{\mathrm{v}}$ & $1.3 \mathrm{~b}$ & $20 \mathrm{~b}$ & $26 \mathrm{~b}$ \\
\hline No & $26 a$ & $3.9 \mathrm{a}$ & $830 \mathrm{a}$ & $1605 \mathrm{a}$ \\
\hline \multicolumn{5}{|l|}{ Magnolia } \\
\hline Yes & $25 \mathrm{~b}^{\mathrm{v}}$ & $1.2 \mathrm{~b}$ & $26 \mathrm{~b}$ & $34 \mathrm{~b}$ \\
\hline No & $30 \mathrm{a}$ & $4.0 \mathrm{a}$ & 299 a & $579 \mathrm{a}$ \\
\hline
\end{tabular}


more after planting was difficult and may be ineffective (Tate 1980; Watson and Clark 1993), implying that it would be advisable to remediate sooner, as Harris and Day (2010) also describe. Earlier remediation, beginning at planting as in the current study, may require fewer inputs and be more effective at reducing root defects in the long term.

Less bending stress was required to winch trees of all taxa to three degrees or more trunk tilt at 18 months (2011) than six months (2010) after planting (Figure 5). Except for Magnolia, differences between years 2010 and 2011 were small or not significant at one and two degrees tilt. Others found an increase with time in bending stress required to tilt the same Acer and Ulmus trunks in the first two years followed by a reduction in stress in years three and four (Gilman et al. 2015a). This suggests an increase with time in vulnerability to windthrow in the first few years after planting.

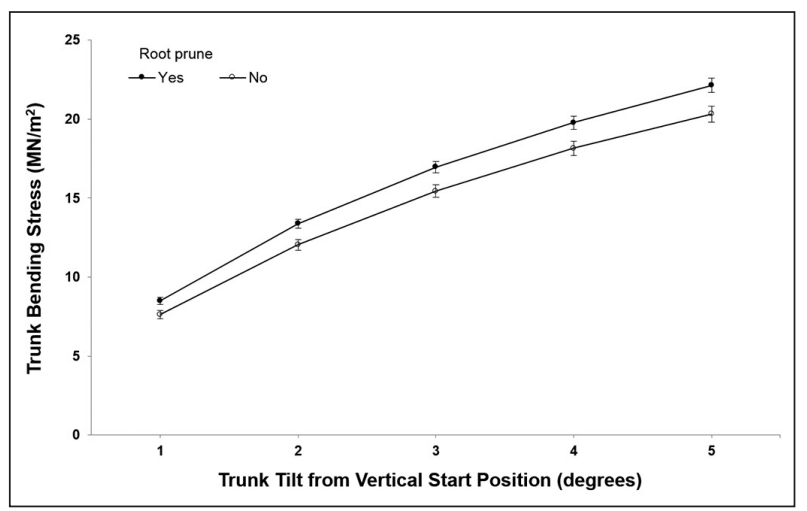

Figure 4. Effect of root pruning at landscape planting on bending stress required to tilt Acer trunks to five degrees; difference between pruned and not pruned was significant at $\boldsymbol{P}<0.02$ for each angle; $\mathrm{n}=20$, mean across retention time and year (2010 and 2011) due to insignificant interaction $(P>$ 0.29). Bars indicate standard error.

\section{CONCLUSIONS}

Retention time in nursery containers of three sizes had little impact on measurements of aboveground growth or physiological stress for any taxa, except for Magnolia trunk diameter growth in one of four years after landscape planting. Acer-but not Magnolia-visual imprint on the root system four years after landscape planting increased with retention time in $11 \mathrm{~L}$ and $57 \mathrm{~L}$ nursery containers as a result of root deflection occurring up to six years earlier in the containers. This supports other work showing that many roots deflected by container walls remain

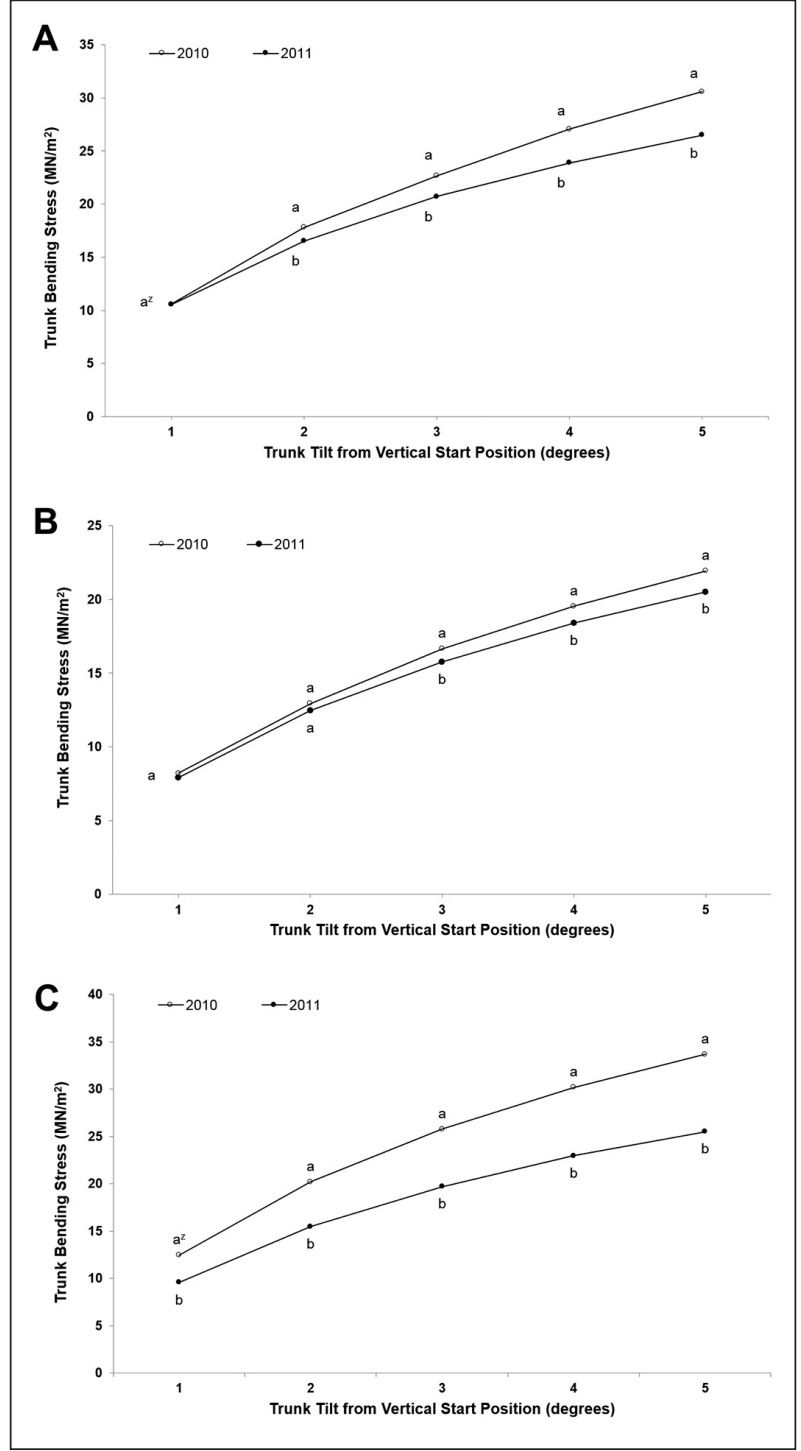

Figure 5. Effect of year after planting on bending stress required to tilt $\operatorname{UImus}(\mathrm{n}=20, A), \operatorname{Acer}(\mathrm{n}=40, B)$, and Magnolia ( $n=40, C)$ trunks to five degrees; mean across retention time due to insignificant interaction $(P>0.12)$.

in that position to become larger. Acer retained in $170 \mathrm{~L}$ containers for the longest time period - which corresponded to the shortest retention time in the two smaller containers-were slightly less anchored after planting into the landscape than trees retained for a shorter period (Figure 2). However, anchorage - as measured by lateral winching-for the other two taxa tested was not impacted by retention time. These results indicate that root systems of these three taxa have the capacity to adapt to varying retention times in containers by creating different but equally stable root architecture in the first few 
years after planting. Results could have been different with longer retention times or different containers, although there is some evidence that container type may play a small role (Gilman et al. 2016).

Pruning to remove roots and substrate on the root ball periphery at planting, by root ball shaving, had little (aboveground growth) or no (anchorage to the soil) impact on Magnolia in the first four years after landscape planting. However, root pruning nearly eliminated circling roots and the visual imprint from roots deflected in containers on both taxa tested (Magnolia and Acer) and improved anchorage slightly (10\%) for Acer. Effect of retention time or root pruning at planting on long-term root architecture, health, or anchorage cannot be drawn from this study; longterm studies over decades are needed to test this.

Acknowledgments. Thanks to innumerable Florida nursery operations and the Florida Nursery Growers and Landscape Association for financial support for this project.

\section{LITERATURE CITED}

Balisky, A.C., P. Salonius, C. Walli, and D. Brinkman. 1995. Seedling roots and forest floor: Misplaced and neglected aspects of British Columbia's reforestation effort? Forestry Chronicle 71:59-65.

Burdett, A.N. 1978. Control of root morphogenesis for improved stability in container-grown lodgepole pine. Canadian Journal of Forest Research 8:483-486.

Burns, R.M., and B.H. Honkala. 1990. Silvics of North America: 1. Conifers; 2. Hardwoods. Agriculture Handbook 654, U.S. Department of Agriculture, Forest Service, Washington, D.C. vol. 2. $877 \mathrm{pp}$.

Coutts, M.P. 1983. Root architecture and tree stability. Plant and Soil 71:171-188.

Coutts, M.P., C. Walker, and A.C. Burnand. 1990. Effects of establishment method on root form of lodgepole pine and Sitka spruce and on the production of adventitious roots. Forestry 63:143-159.

Dunn, G.M., J.R. Huth, and M.J. Lewty. 1997. Coating nursery containers with copper carbonate improves root morphology of five native Australia tree species used in agroforestry systems. Agroforestry Systems 37:143-155.

Fourcaud, T., X. Zhang, and A. Stokes. 2008. Understanding the impact of root morphology on overturning mechanisms: A model approach. Annals of Botany 101:1267-1280.

Gilman E.F., M. Paz, and C. Harchick. 2016. Effect of container type and root pruning on growth and anchorage after planting Acer rubrum L. into landscape soil. Arboriculture \& Urban Forestry 42:73-83.

Gilman, E.F., and C. Harchick. 2014. Root system morphology influences lateral stability of Swietenia mahagoni. Arboriculture \& Urban Forestry 40:27-35.
Gilman, E.F., and C. Wiese. 2012. Root pruning at planting and planting depth in the nursery impact root system morphology and anchorage. Arboriculture \& Urban Forestry 38:232-239.

Gilman, E.F., and M.E. Kane. 1990. Root growth of red maple following planting from containers. HortScience 25:527-528.

Gilman, E.F., J. Miesbauer, C. Harchick, and R.C. Beeson. 2014. Impact of tree size and container volume at planting, mulch, and irrigation on Acer rubrum L. growth and anchorage. Arboriculture \& Urban Forestry 39:173-181.

Gilman, E.F., M. Paz, and C. Harchick. 2010. Root ball shaving improves root systems on seven tree species in containers. Journal of Environmental Horticulture 28:13-18.

Gilman, E.F., M. Paz, and C. Harchick. 2015a. Nursery planting depth, mulch application, and root pruning at landscape planting affect tree health and anchorage. Arboriculture \& Urban Forestry 41:75-87.

Gilman, E.F., M. Paz, and C. Harchick. 2015b. Retention time in three nursery container volumes impacts root architecture. Arboriculture \& Urban Forestry 41:146-154.

Gilman, E.F., M. Paz, and C. Harchick. 2015c. Container and landscape planting depth and root ball shaving affects Magnolia grandiflora root architecture and landscape performance. Arboriculture \& Urban Forestry 41:260-269.

Harris, J.R., and S. Day. 2010. Planting depth at onset of container production and subsequent root ball remediation at transplanting of pin oak and linden. HortScience 45:1793-1797.

Harris, R.W., W.B. Davis, N.W. Stice, and D. Long. 1971. Root pruning improves nursery tree quality. Journal American Society Horticulture Science 96:105-108.

Krasowski, M.J. 2003. Root system modifications by nursery culture reflect on post-planting growth and development of coniferous seedlings. Forestry Chronicle 79:882-891.

Lindgren, O., and G. Örlander. 1978. A study on root development and stability of 6- to 7-year old container plants. pg. 142-144. In: E. Van Eerden and J.M. Kinghorn (Eds.). Proceedings of the Root Form of Planted Trees Symposium, Victoria, British Columbia, Canada, 16-19 May 1978. Canadian Forest Service, B.C., Joint Report No. 8.

Lindström, A., and G. Rune. 1999. Root deformation in plantations of container-grown Scots pine trees: Effects on root growth, tree stability, and stem straightness. Plant and Soil 217:29-37.

Lindström, A., C. Hellqvist, and E. Stattin. 2005. Mini SeedlingsA New Forest Regeneration System. pp. 56-58. In: The Thin Green Line: A symposium on the state-of-the-art in reforestation. Ontario Forest Research Institute, Ontario Ministry of Natural Resources, 1235 Queen Street East Sault Ste. Marie, Ontario, Canada P6A 2E5.

Marshall, M.D., and E.F. Gilman. 1998. Effects of nursery container type on root growth and landscape establishment of Acer rubrum L. Journal of Environmental Horticulture 16:55-59.

Ortega, U., J. Majada, A. Mena-Petite, J. Sanchez-Zabala, N. RodriguezItturrizar, K. Txarterina, J. Azpitarte, and M. Duñabeitia. 2006. Field performance of Pinus radiata D. Don produced in nursery with different types of containers. New Forests 31:97-112.

Robert, J.A., and B.S. Lindgren. 2006. Relationships between root form and growth, stability, and growth in planted versus naturally regenerated lodgepole pine in north-central British Columbia. Canadian Journal of Forest Research 36:2642-2653. 
Salonius, P., K. Beaton, and B. Roze. 2000. Effects of cell size and spacing on root density and field performance of containerreared black spruce. Information Report M-X-208E, Canadian Forest Service, Atlantic Forestry Centre, Frederickton, New Brunswick, Canada.

Spomer, A. 1980. Container soil water relations: production, maintenance, and transplanting. Journal of Arboriculture 6:315-320.

Stokes, A. 1999. Strain distribution during anchorage failure of Pinus pinaster Ait. at different ages and tree growth response to wind-induced root movement. Plant and Soil 217:17-27.

Struve, D.K., L. Burchfield, and C. Maupin. 2000. Survival and growth of transplanted large- and small-caliper red oaks. Journal of Arboriculture 26:162-169.

Tate, R.L. 1980. Detection, description and treatment of girdling roots on urban Norway maple trees. Ph.D. Thesis, University of Michigan.

Watson, G.W. 1985. Tree size affects root regeneration and top growth after transplanting. Journal of Arboriculture 11:37-40.

Watson, G.W., and S. Clark. 1993. Regeneration of girdling roots after removal. Journal of Arboriculture 19:278-280.

\author{
Edward F. Gilman (corresponding author) \\ University of Florida \\ Environmental Horticulture \\ 1533 Fifield Hall \\ Gainesville, Florida 32611, U.S. \\ egilman@ufl.edu
}

Maria Paz

University of Florida

Environmental Horticulture

1533 Fifield Hall

Gainesville, Florida 32611, U.S.

\section{Chris Harchick \\ University of Florida \\ Environmental Horticulture \\ 1533 Fifield Hall}

Gainesville, Florida 32611, U.S.
Résumé. La situation d'arbres vivants renversés (chablis) par le vent lors de tempêtes a été attribuée à l'architecture racinaire déficiente en pépinière. Les deux objectifs de cette étude étaient d'évaluer l'influence du délai de rétention dans trois contenants de pépinière successivement plus grands puis l'impact de l'élagage des racines lors de la plantation sur l'établissement, l'ancrage et l'architecture racinaire durant les quatre premières années suivant la plantation. Tous les arbres ont été maintenus dans trois contenants successivement plus grands $(11,57$ et $170 \mathrm{~L})$ sur une période de 32 mois avec des délais de rétention divers pour chacun. Le délai de rétention a eu peu d'influence sur le potentiel hydrique du xylème suivant leur plantation pour l'Acer rubrum et l'Ulmus parvifolia. Il y avait peu de différences dans la croissance des tiges selon les délais de rétention. À l'exception des Acer, le délai de rétention na eu qu'une influence négligeable sur l'ancrage. La taille périphérique des racines sur les mottes extraites des contenants de $170 \mathrm{~L}$ lors de la plantation n'a eu aucun impact sur la croissance, sauf l'année suivant immédiatement la plantation. Cependant, l'élagage des racines a amené une réduction spectaculaire des racines descendantes et encerclantes quatre ans après la plantation malgré les déformations des racines lors de leur séjour dans le dernier des contenants de pépinière. Malgré que l'élagage des racines n'ait eu aucune influence sur la contrainte de flexion requise pour le treuillage des troncs des Magnolia quel que soit le degré d'inclinaison du tronc, une contrainte de flexion supérieure d'environ $10 \%$ a été nécessaire pour treuiller les troncs des Acer jusqu'à cinq degrés d'inclinaison lorsque les mottes racinaires avaient été taillées lors de la plantation.

Zusammenfassung. Das Unterbringen von Bäumen in der Landschaft während Sturm wird beeinflusst durch dienWurzelarchitektur in den Baumschulen. Die Ziele dieser Studie bestanden darin, den Einfluss von der Aufenthaltsdauer in drei progressiv größer werdenden Pflanzcontainern zu bewerten, sowie Wurzelrückschnitt beim Auspflanzen, auf die Etablierung, die verankerung und die Wurzelarchitektur in den ersten vier Jahren nach der Verpflanzung. Alle Bäume wurden in drei jeweils größer werdenden Containern $(11,57$, and $170 \mathrm{~L})$ für insgesamt 32 Monate mit unterschiedlichen Verweilzeiten in jeder Größe gezogen. Die Verweildauer hatte nur wenig Einfluss auf das Post-Xylem-WasserPotential bei Acer rubrum und Ulmus parvifolia. Es gab wenige Unterschiede in dem Wachstum innerhalb des Topfes bei allen Verweilzeiten. Außer bei Acer, da hatte die Verweildauer einen erkennbaren Einfluss auf die Verankerung. Ein Wurzelrückschnitt durch „Rasieren“ der Ballenperipherie eines 1701 Containers bei der Pflanzung hatte keinen Einfluss auf das Wachstum außer für ein Jahr nach der Verpflanzung. Wie auch immer, das Wurzelschneiden führte vier Jahre nach der Verpflanzung durch die Biegung der Wurzeln in dem letzten Pflanzbehälter zu einer dramatischen Reduktion von Würgewurzeln. Obwohl der Wurzelrückschnitt keinen Einfluss auf den Biegestress beim Ziehen von MagnoliaStämmen hatte, war schätzungsweise $10 \%$ mehr Biegestress für das Ziehen bis zu fünf Grad Neigung von Acer-Stämmen erforderlich, wenn die Wurzelballen beim Pflanzen „rasiert“ wurden. 